\title{
Characteristics of Mathematics Teachers' Practices and Beliefs about Project-based Learning and Teaching Mathematics in Ukraine
}

\author{
Nina Tarasenkova ${ }^{1, *}$, Iryna Akulenko², Mykhailo Burda ${ }^{3}$, Kira Hnezdilova ${ }^{4}$, Oleh Zhydkov² \\ ${ }^{1}$ Department of Mathematics and Methods of Teaching Mathematics, Educational-Scientific Institute of Informational and \\ Educational Technologies, Bohdan Khmelnytsky National University of Cherkasy, Ukraine \\ ${ }^{2}$ Department of Algebra and Calculus, Educational-Scientific Institute of Informational and Educational Technologies, Bohdan \\ Khmelnytsky National University of Cherkasy, Ukraine \\ ${ }^{3}$ Department of Mathematical and Computer Education, The Institute of Pedagogy of the National Academy of Pedagogical Sciences of \\ Ukraine, Ukraine \\ ${ }^{4}$ Department of Pre-school Education, Educational-Scientific Institute of Pedagogical Education, Social work and Arts, Bohdan \\ Khmelnytsky National University of Cherkasy, Ukraine
}

Received September 10, 2020; Revised November 16, 2020; Accepted November 29, 2020

\section{Cite This Paper in the following Citation Styles}

(a): [1] Nina Tarasenkova, Iryna Akulenko, Mykhailo Burda, Kira Hnezdilova, Oleh Zhydkov, "Characteristics of Mathematics Teachers' Practices and Beliefs about Project-Based Learning and Teaching Mathematics in Ukraine," Universal Journal of Educational Research, Vol. 8, No. 12A, pp. 7631 - 7642, 2020. DOI: 10.13189/ujer.2020.082549.

(b): Nina Tarasenkova, Iryna Akulenko, Mykhailo Burda, Kira Hnezdilova, Oleh Zhydkov (2020). Characteristics of Mathematics Teachers' Practices and Beliefs about Project-Based Learning and Teaching Mathematics in Ukraine. Universal Journal of Educational Research, 8(12A), 7631 - 7642. DOI: 10.13189/ujer.2020.082549.

Copyright $\odot 2020$ by authors, all rights reserved. Authors agree that this article remains permanently open access under the terms of the Creative Commons Attribution License 4.0 International License

\begin{abstract}
This empirical study determines the obvious and hidden factors that affect the Ukrainian Mathematics teachers to use Project-Based Learning and Teaching (PBL and PBT) Mathematics. A survey of 126 practicing Mathematics teachers was conducted using a Standard closed ended questionnaire. The study confirms that modern Mathematics teachers believe that it is impossible to teach Mathematics for modern students without using PBL and PBT. On the one hand, teachers demonstrate their beliefs in these educational techniques. On the other hand, the survey reveals hidden factors that are inhibitory in the practice of PBL and PBT Mathematics. The study shows the following statistically confirmed factors in teachers' beliefs concerning the use of PBL and PBT Mathematics: Content-Technological Factor; Result \& Age Factor; Factor of the Target Audience on the expediency of using PBL and PBT Mathematics; Teacher's Overload Factor; Praxeological Factor; Locality Factor; Teacher's Awareness Spectrum Factor. The previous assumption that the experience of a Mathematics teacher is an influential factor in the use of PBL and PBT has not been statistically confirmed. The results show that an influential factor is the
\end{abstract}

Locality Factor. So, it's important if a teacher teaches Mathematics in a city or a village. Its origins (genesis and causes) and the consequences of this factor influence on educational processes in Ukraine need more detailed study.

Keywords Math Education, Project-based Learning and Teaching, Math Teachers' Beliefs

\section{Introduction}

The modern world initiates profound transformations in the content and organization of the learning and teaching process. Researchers and teachers-practitioners investigate what content for education is relevant for the students to master the subject matter better and to apply the acquired knowledge and skills successfully in their further life and future career. How should learning be organized so that the learners could successfully and effectively adapt to the fleeting and changing conditions of life and work?

The innovative target priority of the educational process 
is the creation of favourable conditions for developing such important personality traits as independence, criticality, the ability to work in the team, to determine the goals of the activity and the ways to achieve them since these personal qualities are the key ones to a person's successful life in the 21st century (according to the authors of the international study [1]). Changing emphases on educational targets caused by the rapid development of a society in general and the education sector in particular, encourage educators to seek new educational practices or to revive former ones adapted to today's conditions. Along with the use of the latest learning and teaching techniques (online, offline, blended learning), the application of Project-Based Learning and Teaching (PBL and PBT) is considered to be promising. PBL and PBT are not new in the world practice in general and for Ukrainian schoolchildren and teachers in particular. But these educational techniques were not used in the Ukrainian education for a long time. However, nowadays, educators and teachers focus on this method due to its powerful potential in the context of new challenges to be met by the modern education system.

The appeal to PBL and PBT in the process of teaching Mathematics in a modern Ukrainian school is motivated by the fact that the design of the educational process based on these educational technologies creates favourable conditions for the formation of most in-demand qualities of students in modern society. In addition, it should be noted that the national experience of PBL and PBT application shows some reservations in their implementation in order to avoid negative consequences and poor educational outcomes. Our observations show that one of the factors influencing PBL and PBT Mathematics is the practicing Mathematics teachers' beliefs regarding their use. The article focuses on the study of this aspect of applying PBL and PBT Mathematics.

\subsection{Background of the Study}

The prior concept included to the theoretical framework of the study is the concept of "Project-Based Learning". The organization, content and methods of conducting PBL and PBT are in the focus of numerous scientific studies in the Ukrainian and foreign pedagogy $[2 ; 3 ; 4 ; 5 ; 6]$. Dewey [7; 8], Kilpatrick [9], Makarenko [10] focused on the genesis, historiography, the methodological and philosophical foundations of the PBL and PBT.

The profound literature reviews of the PBL in K-12 settings were presented by Thomas [12] and by Condliffe, Quint, Visher, Bangser, Drohojowska, Saco \& Nelson [13]. They stated that a wide range of scientific studies use this concept in a slightly different semantic meaning. Research analysis shows that a wide range of scientific studies consider the practice of the PBL in school, and outside, in the workplace and the community (Maida [11],
Thomas [12], Condliffe, Quint, Visher, Bangser, Drohojowska, Saco, Nelson [13]). Based on the scientists' research, we would like to highlight characteristic properties of the PBL and PBT. Markham [5] at Buck Institute for Education defines project-based learning as "a systematic teaching method that engages students in learning knowledge and skills through an extended inquiry process structured upon complex, authentic questions and carefully designed products and tasks". Unfortunately, this definition does not emphasize the differences, characteristics, the essence of this method of teaching. Its essence according to Balkevičius, Mažeikienè and Švedienė [13] is to help students to look at learning as a self-regulating process, in which each student must form in his/her skills of planning, organizing and implementing activities.

In our opinion, PBL and PBT characteristics were clearly defined by Mohedo and Bújez. According to Mohedo and Bújez [15], this is a method through which students learn, apply and research (putting into practice their abilities related to communication and the sharing and management of information). Learning is based on the formulation of a problem as the starting point for the learning process. The decisive question is how this problem dictates the direction in which the learning process has to go; more importance is attached to asking questions than finding answers. The students' experience is implicitly part of the learning process that takes place, and the linking of problems to individual experience increases levels of motivation. Task based learning is a central part of the learning process since tasks need to be solved through information searches and decision-making. Students learn to relate specific or empirical experience to theory, which is a decisive question in terms of the application of knowledge and, above all, in the ability to analyse information. Learning based on group work is the last principle through which most learning processes take place, and where there is also an implicit development of personal competences related to the management of cooperation processes. It should be noted that the purpose of the activity in the PBL and PBT is decomposed in a number of goals (tasks), one of which is the creation of a real product, which is considered to be a subjectively new result for students. This approach to definition and qualitative analysis of PBL and PBT serve as a foundation for this research.

The researchers Condliffe, Quint, Visher, Bangser, Drohojowska, Saco and Nelson [13] describe how PBL has been enacted in K-12 setting, assessed the PBL implementation and effectiveness, and recommended priorities for its advancing. Researchers state that it is a student-centered process that meets students' needs and encourages them to become more involved in their own learning process. Douladeli [16] points out that PBL and PBT are successful when such essential elements are fulfilled: 1) teachers engage students' interest and "need 
to know" and at the same time stimulate them by making a capturing driving question (Larmer and Mergendoller [20]); 2) students are in charge of deciding whether they will use resources, how they will cooperate and communicate in order to achieve the goal of their challenging project (Frey [21]); 3) critical thinking is enhanced and students can easily conduct their inquiry as well as innovate by exploiting sometimes the advantages of technology (Larmer and Mergendoller [20]); 3) technological improvement gives students the opportunity to interact and simultaneously submit questions and answers (Douladeli [16]); 4) feedback and revision are also important before student's presentation in front of a real audience (Frey [21]).

Special attention is paid for PBL and PBT Mathematics (Lee [26], Krajcik and Blumenfeld [27], Ramadhani \& Fitri [32]). Lee [26] generalizes the practices of this method application in teaching Mathematics and identifies the following elements that are essential for its effective design: 1) an entry event; 2) a driving question; 3) Need-to-Knows (NTKs); 4) the project planning form; 5) the project calendar; 6) a scaffolding instruction; 7) a project rubric.

Thomas [12] states a positive relationship between the PBL and the quality of student learning, and identifies some common challenges that teachers face when implementing PBL and PBT. Scientific studies (Efstratia [16], Fernandes, Mesquita, Flores and Lima [18]) also point out difficulties and disadvantages of PBL (PBT). Among others, authors emphasize: unrealised and unperceived roles of students in a project team, lack of students' social competency, lack of students' leadership competency, unrealised role of students completing task assigned by a lecturer, unrealised responsibility of a teacher for initiating dialogue with students. Grant and Hill [28] note that some teachers find implementation of project-based learning to be risky, because, in addition to modifying the teacher's role, it requires teachers to tolerate changes to the traditional learning environment (e.g., noise level, student collaboration, and student movement) and feel comfortable with flexibility in classroom management. The researchers state that teachers face accountability pressures; and coping with the changes and levels of ambiguity can be difficult. Therefore, insufficient or negative experience of teachers in the use of PBL and PBT is a brake on improving the educational process through the introduction of PBL and PBT.

Some studies (Albion and Ertmer [22; 23]; Block and Hazelip [24], Calderhead [25]) underline that practicing teachers' beliefs influence strongly implementation and effectiveness of any innovative instruction technique. In our research (Tarasenkova and Akulenko [19]) we analyse future Mathematics teachers' beliefs (about the nature of Mathematics; about learning Mathematics; about students' mathematics abilities; about students' preparedness for teaching Mathematics using contemporary instructional approaches). We state that students' beliefs strongly influence their self-confidence and self-estimation, the level of the preparedness for teaching Mathematics using innovations.

In her study, Ertmer [14] clarifies the significance of teachers' beliefs about PBL and PBT and why they are critical to consider the way of the implementation of PBL and PBT. The review [14] suggests that teachers' pedagogical beliefs are strongly influenced by personal experiences, vicarious experiences (observing models of other teachers implementing the innovation), and sociocultural influences. At the same time, the study states that many teachers' personal experiences do not support a belief in PBL and PBT. However, the problem of the impact of practicing Mathematics teachers' beliefs about PBL and PBT requires more careful consideration and analysis to improve its effectiveness in the practice of teaching Mathematics to students. It is also important to understand what aspects of practicing Mathematics teachers' beliefs have a statistically significant effect on teachers' motivation and the practice of using this method in teaching Mathematics.

The article focuses on solving this problem.

\subsection{The Objective of This Study is}

1) to investigate Ukrainian practicing Mathematics teachers' beliefs about the PBL and PBL Mathematics;

2) to identify the obvious and hidden factors that affect the Ukrainian Mathematics teachers to use PBL and PBT Mathematics;

3) to elaborate and present some prospective directions for improving the preparation of the pre-service teachers of Mathematics for providing the PBL and PBT Mathematics.

\section{Materials and Methods}

\subsection{Study Design}

To study Mathematics teachers' beliefs about the project-based learning and teaching, a survey of practicing Ukrainian Mathematics teachers was conducted. It was carried out by the group of researchers from the Educational-Scientific Institute of Information and Educational Technologies at the Bohdan Khmelnytsky National University of Cherkasy.

Sampling. The questionnaire involved 125 respondents; the sample was random.

\subsection{Data Collection}

Data collection tools: Standard closed ended questionnaire was developed by the researchers based on available literature to evaluate the teacher's beliefs 
concerning the PBL and PBT Mathematics.

Data collection technique: The data was collected within one month. Every participant filled the questionnaire by him/herself. Each questionnaire took from 10 to 15 minutes to be filled out, there were no missing questionnaires.

Ethical considerations: The purpose of the study was explained to every participant and the participants were reminded that the information should be confidential and used only for the purpose of the study.

\subsection{Data Analysis Technique}

Factor analysis was used to process the survey results. It helped: 1) to examine the relationships of the input variables (each grouping of variables is determined by the factor that gives them the maximum); 2) to identify factors that cause the relationship of input variables; 3) to calculate the numerical values of factors as new, integral variables. The data was analysed and presented in the forms of tables, graphs and figures.

\section{Results}

The survey was administered to efficient, experienced teachers who have an established personal teaching philosophy about PBL and PBT. The participants' work experience as a Mathematics teacher varied: for 1-5 years (21\%), 6-10 years (21\%), 11-15 years (14\%), 16-20 years (4\%), 21-25 years (11\%), 26 years and longer $(29 \%) .52 \%$ of respondents work in city schools, $48 \%$ - in rural ones.

In general, $88 \%$ of respondents agreed that teaching Mathematics in modern school is impossible without PBL and PBT. The questionnaire showed that $80 \%$ of Mathematics teachers use PBL and PBT in their work often or sometimes; this fact bears witness to teachers' beliefs about the great value and importance of schoolchildren's project activity in learning and teaching Mathematics. It should be noted that the percentage of those who use the PBL and PBT Mathematics is unevenly distributed among teachers according to their work experience. The teachers having 16-20-year and 21-25-year work experience often or sometimes use this method in their work (100\%); the teachers having 1-5-year work experience do not use it at all (13\%). This fact shows that the newly qualified teachers do not have sufficient preparation for the organization of the schoolchildren's PBL and PBT Mathematics and are not able to use it. In support of this conclusion, $12 \%$ of them point out that they do not have sufficient knowledge about the essence of project methodology to use it in practice. The largest number of those who often use PBL and PBT Mathematics in their work (35\%) is presented among the teachers having 11-15-year work experience. The teachers with work experience of more than 25 years always (19\%) or sometimes $(70 \%)$ use this method in Mathematics educational process.

Most respondents (82\%) agree PBL and PBT helps schoolchildren to master the new ways of mathematical activity and to learn new mathematical facts. However, it is less effective for learning new mathematical concepts. Concerning the expediency of using the PBL and PBT Mathematics the students of different age groups, most respondents $(66 \%)$ consider it expedient to use this method in K10-11. At the same time, 52\% of respondents consider it to be an efficient method of teaching Mathematics in K7-9, 23\% of respondents - the students in K-5 and K-6 settings. Thus, there is a steady tendency in the teachers' beliefs concerning the expediency of using PBT of Mathematics in K 5-11. According to the respondents, the use of projects in the educational activities in K 5-6 is less effective.

In order to find out the reasons (factors) of the common variability of variables (according to the results of the questionnaire), Factor Analysis was used. Factor analysis follows the sequence: 1) the correlation matrix for all variables was calculated (in our case, data received from the teachers who participated in the analysis); 2) factors were separated by using the main components analysis method; 3) factors were rotated to simplify the structure (Varimax rotation with Kaiser normalization was used); 4) factors were interpreted; the SPSS 19.0 software package was used.

To simplify the presentation of data in correlation tables, we introduced the notation of variables $\mathbf{V}_{\mathbf{1}}-\mathbf{V}_{\mathbf{2 2}}$ (Table $1)$. 
Table 1. Notation of Variables

\begin{tabular}{|c|c|}
\hline $\begin{array}{c}\text { Notation of a } \\
\text { variable }\end{array}$ & Variable \\
\hline $\mathrm{V}_{1}$ & City/village \\
\hline $\mathrm{V}_{2}$ & Experience as a Mathematics teacher \\
\hline $\mathrm{V}_{3}$ & Grade levels where the teacher works simultaneously \\
\hline $\mathrm{V}_{4}$ & Experience in application of PBT Mathematics \\
\hline $\mathrm{V}_{5}$ & The influence of PBL and PBT on the effectiveness of students' learning of new mathematical concepts \\
\hline $\mathrm{V}_{6}$ & The influence of PBL and PBT on the effectiveness of learning new mathematical facts \\
\hline $\mathrm{V}_{7}$ & The influence of PBL and PBT on the effectiveness of learning new ways of mathematical activity \\
\hline $\mathrm{V}_{8}$ & Significance of students' project activities for studying Mathematics in modern conditions \\
\hline $\mathrm{V}_{9}$ & The expediency of using PBL and PBT in teaching Mathematics in grades 5-6 \\
\hline $\mathrm{V}_{10}$ & The expediency of using PBL and PBT in teaching Mathematics in grades 7-9 \\
\hline $\mathrm{V}_{11}$ & The expediency of using PBL and PBT in teaching Mathematics in grades 10-11 \\
\hline $\mathrm{V}_{12}$ & The respondent has sufficient, in his opinion, knowledge about the essence of PBL and PBT \\
\hline $\mathrm{V}_{13}$ & Knowledge of the PBL and PBT essence is not important for a teacher \\
\hline $\mathrm{V}_{14}$ & The importance of the teachers knowledge about the essence of students' project activities \\
\hline $\mathrm{V}_{15}$ & The importance of the teachers knowledge about the stages of the educational project \\
\hline $\mathrm{V}_{16}$ & The importance of the teachers knowledge of the interdisciplinary connections of mathematics topics \\
\hline $\mathrm{V}_{17}$ & The importance of the teachers knowledge of modern Internet resources \\
\hline $\mathrm{V}_{18}$ & The importance of the teachers knowledge of the methods of reporting on completed projects \\
\hline $\mathrm{V}_{19}$ & $\begin{array}{c}\text { The importance of the teachers knowledge about the features of evaluating the results of students' project } \\
\text { activities }\end{array}$ \\
\hline $\mathrm{V}_{20}$ & The importance of the teachers knowledge of ways to motivate students to implement projects \\
\hline $\mathrm{V}_{21}$ & The importance of teachers knowledge about ICT in education \\
\hline $\mathrm{V}_{22}$ & The importance of other teachers knowledge for PBT Mathematics \\
\hline
\end{tabular}

Based on the correlation tables, we constructed correlation pleiades taking into account the identified relationships between variables with a correlation coefficient greater than 0.4 (Figures 1 and 2). Since no correlations with a correlation coefficient value greater than 0.4 were found between the group of variables $\mathbf{V}_{5}, \mathbf{V}_{\mathbf{6}}$, $\mathbf{V}_{\mathbf{7}}, \mathbf{V}_{\mathbf{8}}, \mathbf{V}_{\mathbf{1 0}}, \mathbf{V}_{\mathbf{1 1}}$ and the group of variables $\mathbf{V}_{\mathbf{1 4}}, \mathbf{V}_{\mathbf{1 5}}, \mathbf{V}_{\mathbf{1 6}}$, $\mathbf{V}_{17}, \mathbf{V}_{18}, \mathbf{V}_{\mathbf{2 0}}, \mathbf{V}_{\mathbf{2 1}}$, two correlation galaxies were formed (Figure 1-2).

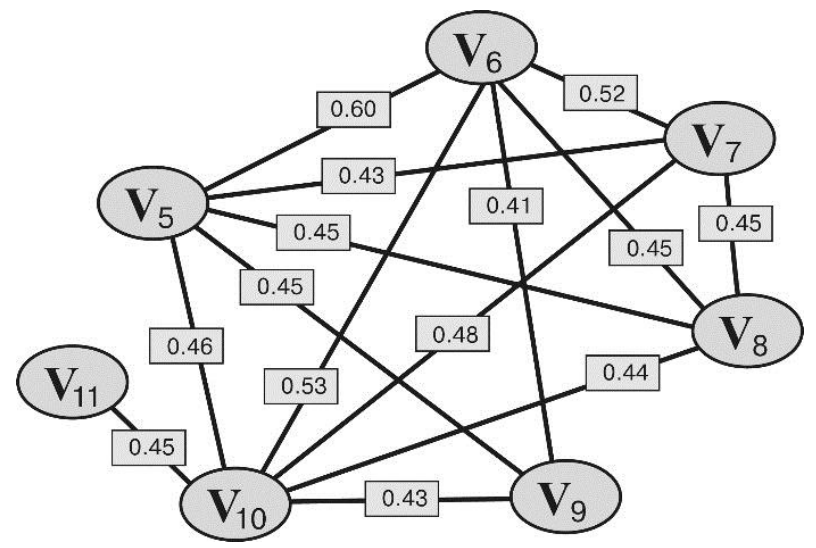

Figure 1. Correlation galaxy 1

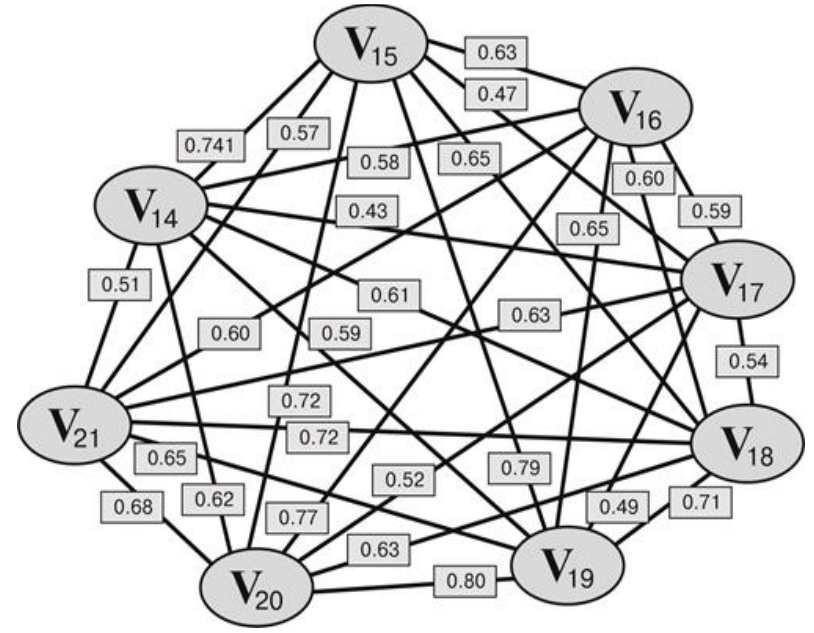

Figure 2. Correlation galaxy 2

The numerical value obtained (0.796) of the Kaiser-Meyer-Olkin sampling adequacy demonstrates a high sample correlation for the factor analysis. The Bartlett spherical criterion indicated a statistically significant result, since correlations between variables differed significantly from zero (Table 2). Table 3 lists the names of variables and grouping results (community). 
Table 2. Measure of sampling adequacy and Bartlett's criterion

\begin{tabular}{|l|c|c|}
\hline \multicolumn{2}{|c|}{ Kaiser-Meyer-Olkin measure of sampling adequacy } & 0.796 \\
\hline \multirow{3}{*}{ Bartlett's test of sphericity } & Approx. Chi-Square & 1134.663 \\
\cline { 2 - 3 } & df & 231 \\
\cline { 2 - 3 } & Sig & 0.000 \\
\hline
\end{tabular}

Table 3. Variables and grouping results (community)

\begin{tabular}{|c|c|c|c|}
\hline № & Names of variables & Input & Output \\
\hline $\mathrm{V}_{1}$ & City/village & 1.000 & 0.856 \\
\hline $\mathrm{V}_{2}$ & Experience as a Mathematics teacher & 1.000 & 0.599 \\
\hline $\mathrm{V}_{3}$ & Grade levels where the teacher works simultaneously & 1.000 & 0.640 \\
\hline $\mathrm{V}_{4}$ & Experience in application of PBT Mathematics & 1.000 & 0.726 \\
\hline $\mathrm{V}_{5}$ & The influence of PBL and PBT on the effectiveness of students' learning of new mathematical concepts & 1.000 & 0.667 \\
\hline $\mathrm{V}_{6}$ & The influence of PBL and PBT on the effectiveness of learning new mathematical facts & 1.000 & 0.713 \\
\hline $\mathrm{V}_{7}$ & The influence of PBL and PBT on the effectiveness of learning new ways of mathematical activity & 1.000 & 0.600 \\
\hline $\mathrm{V}_{8}$ & Significance of students' project activities for studying Mathematics in modern conditions & 1.000 & 0.562 \\
\hline $\mathrm{V}_{9}$ & The expediency of using PBL and PBT in teaching Mathematics in grades 5-6 & 1.000 & 0.758 \\
\hline $\mathrm{V}_{10}$ & The expediency of using PBL and PBT in teaching Mathematics in grades 7-9 & 1.000 & 0.653 \\
\hline $\mathrm{V}_{11}$ & The expediency of using PBL and PBT in teaching Mathematics in grades 10-11 & 1.000 & 0.730 \\
\hline $\mathrm{V}_{12}$ & The respondent has sufficient, in his opinion, knowledge about the essence of PBL and PBT & 1.000 & 0.724 \\
\hline $\mathrm{V}_{13}$ & Knowledge of the PBL and PBT essence is not important for a teacher & 1.000 & 0.698 \\
\hline $\mathrm{V}_{14}$ & The importance of the teachers knowledge about the essence of students' project activities & 1.000 & 0.680 \\
\hline $\mathrm{V}_{15}$ & The importance of the teachers knowledge about the stages of the educational project & 1.000 & 0.791 \\
\hline$V_{16}$ & The importance of the teachers knowledge of the interdisciplinary connections of mathematics topics & 1.000 & 0.715 \\
\hline $\mathrm{V}_{17}$ & The importance of the teachers knowledge of modern Internet resources & 1.000 & 0.608 \\
\hline $\mathrm{V}_{18}$ & The importance of the teachers knowledge of the methods of reporting on completed projects & 1.000 & 0.794 \\
\hline $\mathrm{V}_{19}$ & $\begin{array}{l}\text { The importance of the teachers knowledge about the features of evaluating the results of students' project } \\
\text { activities }\end{array}$ & 1.000 & 0.788 \\
\hline $\mathrm{V}_{20}$ & The importance of the teachers knowledge of ways to motivate students to implement projects & 1.000 & 0.837 \\
\hline $\mathrm{V}_{21}$ & The importance of teachers knowledge about ICT in education & 1.000 & 0.740 \\
\hline $\mathrm{V}_{22}$ & The importance of other teachers knowledge for PBT Mathematics & 1.000 & 0.835 \\
\hline
\end{tabular}


Table 4 shows the characteristics of the separate factors: the number, the sum of the squared loadings, the percentage of the joint dispersion, which is caused by the factor, the corresponding cumulative percentage before and after loading.

Table 4. Total Variance Explained

\begin{tabular}{|c|c|c|c|c|c|c|c|c|c|}
\hline \multirow{2}{*}{ Component } & \multicolumn{3}{|c|}{ Initial Eigenvalues } & \multicolumn{3}{c|}{ Sums of Squared Loadings } & \multicolumn{3}{c|}{ Rotation Sums of Squared Loadings } \\
\cline { 2 - 10 } & Total & $\begin{array}{c}\text { \% of } \\
\text { Variance }\end{array}$ & $\begin{array}{c}\text { Cumulative } \\
\%\end{array}$ & Total & $\begin{array}{c}\% \text { of } \\
\text { Variance }\end{array}$ & $\begin{array}{c}\text { Cumulative } \\
\%\end{array}$ & Total & $\begin{array}{c}\text { \% of } \\
\text { Variance }\end{array}$ & $\begin{array}{c}\text { Cumulative } \\
\%\end{array}$ \\
\hline 1 & 6.086 & 27.662 & 27.662 & 6.086 & 27.662 & 27.662 & 5.563 & 25.286 & 25.286 \\
\hline 2 & 3.335 & 15.160 & 42.822 & 3.335 & 15.160 & 42.822 & 3.713 & 16.879 & 42.165 \\
\hline 3 & 1.573 & 7.149 & 49.971 & 1.573 & 7.149 & 49.971 & 1.478 & 6.718 & 48.883 \\
\hline 4 & 1.457 & 6.623 & 56.594 & 1.457 & 6.623 & 56.594 & 1.385 & 6.294 & 55.177 \\
\hline 5 & 1.194 & 5.426 & 62.020 & 1.194 & 5.426 & 62.020 & 1.269 & 5.769 & 60.947 \\
\hline 6 & 1.055 & 4.794 & 66.814 & 1.055 & 4.794 & 66.814 & 1.171 & 5.323 & 66.269 \\
\hline 7 & 1.014 & 4.608 & 71.423 & 1.014 & 4.608 & 71.423 & 1.134 & 5.153 & 71.423 \\
\hline 8 & .799 & 3.631 & 75.054 & & & & & & \\
\hline 9 & .760 & 3.454 & 78.508 & & & & & & \\
\hline 10 & .641 & 2.914 & 81.422 & & & & & & \\
\hline 11 & .607 & 2.760 & 84.183 & & & & & & \\
\hline 12 & .562 & 2.555 & 86.737 & & & & & & \\
\hline 13 & .488 & 2.220 & 88.957 & & & & & & \\
\hline 14 & .424 & 1.929 & 90.886 & & & & & & \\
\hline 15 & .406 & 1.844 & 92.730 & & & & & & \\
\hline 16 & .367 & 1.667 & 94.397 & & & & & & \\
\hline 17 & .317 & 1.441 & 95.837 & & & & & & \\
\hline 18 & .269 & 1.223 & 97.061 & & & & & & \\
\hline 19 & .219 & .996 & 98.056 & & & & & & \\
\hline 21 & .189 & .861 & 98.917 & & & & & & \\
\hline 22 & .146 & .664 & 99.581 & & & & & & \\
\hline
\end{tabular}

Figure 3 shows an Eigenvalue graph that illustrates selected factors before loading.

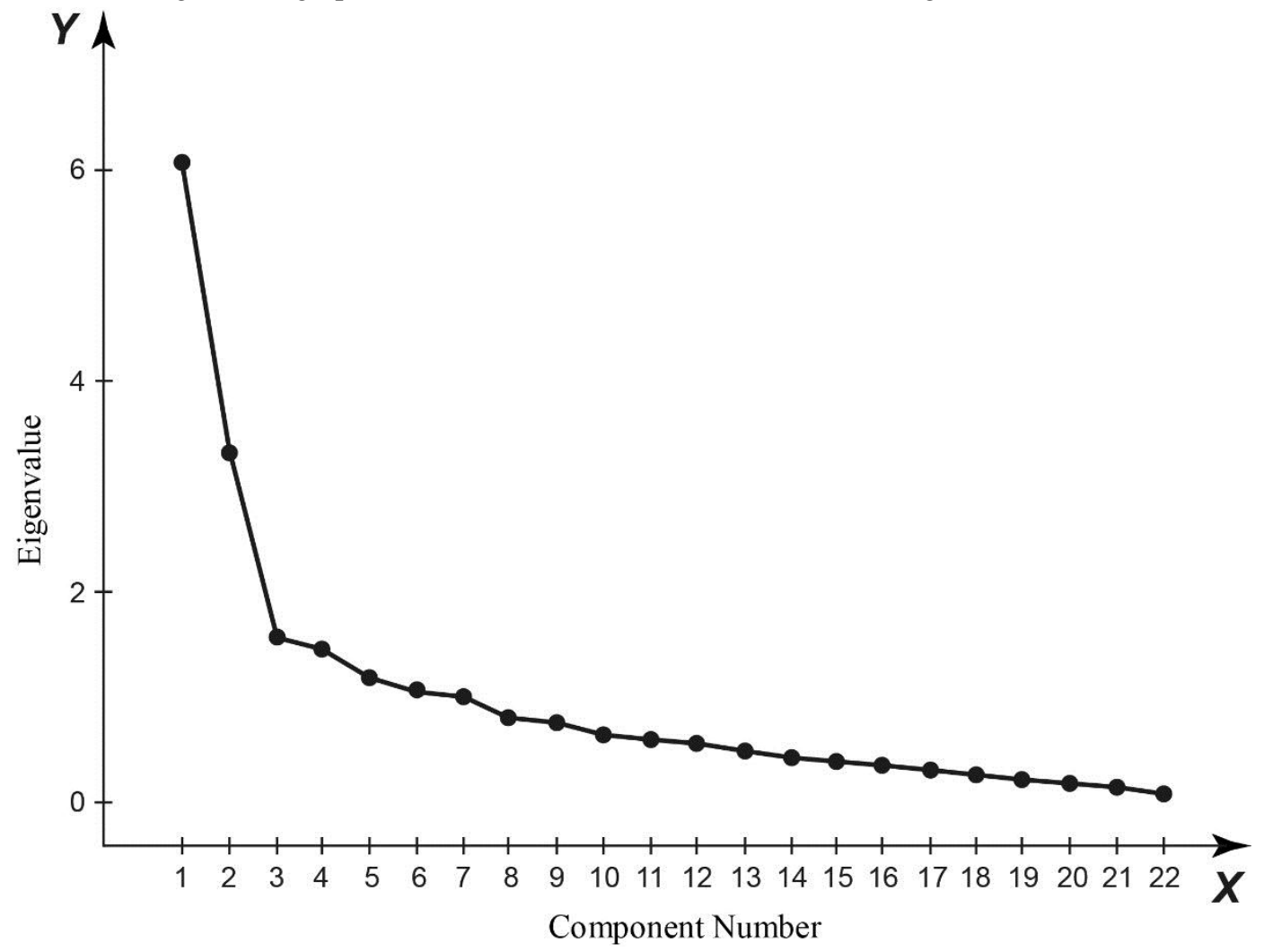

Figure 3. Eigenvalue graph 
Subsequently, the factors were rotated (Table 5) to create a simplified structure (using Rotation Method: Varimax with Kaiser Normalization was used).

Table 5. Rotated Component Matrix

\begin{tabular}{|c|c|c|c|c|c|c|c|c|}
\hline \multirow{2}{*}{ № } & \multirow{2}{*}{ Variables } & \multicolumn{7}{|c|}{ Component } \\
\hline & & 1 & 2 & 3 & 4 & 5 & 6 & 7 \\
\hline $\mathrm{V}_{1}$ & City/village & & & & & & 0.912 & \\
\hline $\mathrm{V}_{2}$ & Experience as a Mathematics teacher & & & -0.547 & & & & \\
\hline $\mathrm{V}_{3}$ & $\begin{array}{l}\text { Grade levels where the teacher works } \\
\text { simultaneously }\end{array}$ & & & & 0.696 & & & \\
\hline $\mathrm{V}_{4}$ & $\begin{array}{c}\text { Experience in application of PBT } \\
\text { Mathematics }\end{array}$ & & & 0.683 & & & & \\
\hline $\mathrm{V}_{5}$ & $\begin{array}{l}\text { The influence of PBL and PBT on the } \\
\text { effectiveness of students' learning of new } \\
\text { mathematical concepts }\end{array}$ & & 0.763 & & & & & \\
\hline $\mathrm{V}_{6}$ & $\begin{array}{l}\text { The influence of PBL and PBT on the } \\
\text { effectiveness of learning new } \\
\text { mathematical facts }\end{array}$ & & 0.813 & & & & & \\
\hline $\mathrm{V}_{7}$ & $\begin{array}{l}\text { The influence of PBL and PBT on the } \\
\text { effectiveness of learning new ways of } \\
\text { mathematical activity }\end{array}$ & & 0.704 & & & & & \\
\hline $\mathrm{V}_{8}$ & $\begin{array}{l}\text { Significance of students' project activities } \\
\text { for studying Mathematics in modern } \\
\text { conditions }\end{array}$ & & 0.682 & & & & & \\
\hline $\mathrm{V}_{9}$ & $\begin{array}{l}\text { The expediency of using PBL and PBT in } \\
\text { teaching Mathematics in grades 5-6 }\end{array}$ & & 0.572 & & & -0.614 & & \\
\hline $\mathrm{V}_{10}$ & $\begin{array}{c}\text { The expediency of using PBL and PBT in } \\
\text { teaching Mathematics in grades 7-9 }\end{array}$ & & 0.753 & & & & & \\
\hline $\mathrm{V}_{11}$ & $\begin{array}{l}\text { The expediency of using PBL and PBT in } \\
\text { teaching Mathematics in grades } 10-11\end{array}$ & & 0.458 & & & 0.701 & & \\
\hline $\mathrm{V}_{12}$ & $\begin{array}{l}\text { The respondent has sufficient, in his } \\
\text { opinion, knowledge about the essence of } \\
\text { PBL and PBT }\end{array}$ & & & 0.789 & & & & \\
\hline $\mathrm{V}_{13}$ & $\begin{array}{c}\text { Knowledge of the PBL and PBT essence } \\
\text { is not important for a teacher }\end{array}$ & & & & 0.775 & & & \\
\hline $\mathrm{V}_{14}$ & $\begin{array}{l}\text { The importance of the teachers } \\
\text { knowledge about the essence of students' } \\
\text { project activities }\end{array}$ & 0.753 & & & & & & \\
\hline $\mathrm{V}_{15}$ & $\begin{array}{l}\text { The importance of the teachers } \\
\text { knowledge about the stages of the } \\
\text { educational project }\end{array}$ & 0.855 & & & & & & \\
\hline $\mathrm{V}_{16}$ & $\begin{array}{l}\text { The importance of the teachers } \\
\text { knowledge of the interdisciplinary } \\
\text { connections of mathematics topics }\end{array}$ & 0.827 & & & & & & \\
\hline $\mathrm{V}_{17}$ & $\begin{array}{l}\text { The importance of the teachers } \\
\text { knowledge of modern Internet resources }\end{array}$ & 0.675 & & & & & & \\
\hline $\mathrm{V}_{18}$ & $\begin{array}{l}\text { The importance of the teachers } \\
\text { knowledge of the methods of reporting on } \\
\text { completed projects }\end{array}$ & 0.834 & & & & & & \\
\hline $\mathrm{V}_{19}$ & $\begin{array}{l}\text { The importance of the teachers } \\
\text { knowledge about the features of } \\
\text { evaluating the results of students' project } \\
\text { activities }\end{array}$ & 0.879 & & & & & & \\
\hline $\mathrm{V}_{20}$ & $\begin{array}{l}\text { The importance of the teachers } \\
\text { knowledge of ways to motivate students } \\
\text { to implement projects }\end{array}$ & 0.884 & & & & & & \\
\hline $\mathrm{V}_{21}$ & $\begin{array}{l}\text { The importance of teachers knowledge } \\
\text { about ICT in education }\end{array}$ & 0.817 & & & & & & \\
\hline $\mathrm{V}_{22}$ & $\begin{array}{l}\text { The importance of other teachers } \\
\text { knowledge for PBT Mathematics }\end{array}$ & & & & & & & 0.902 \\
\hline
\end{tabular}




\section{Discussion}

Interpretation of factors. As a result of rotation, the following factors have been identified (Table $6-12$ ) that influence the use of PBL and PBT Mathematics by a teacher.

Table 6. Factor 1 (Content-Technological Factor)

\begin{tabular}{|c|c|c|}
\hline № & Variables & \\
\hline $\mathbf{V}_{\mathbf{2 0}}$ & $\begin{array}{c}\text { The importance of the teachers knowledge of } \\
\text { ways to motivate students to implement projects }\end{array}$ & 0.884 \\
\hline $\mathbf{V}_{\mathbf{1 9}}$ & $\begin{array}{c}\text { The importance of the teachers knowledge about } \\
\text { the features of evaluating the results of students' } \\
\text { project activities }\end{array}$ & 0.879 \\
\hline $\mathbf{V}_{\mathbf{1 5}}$ & $\begin{array}{c}\text { The importance of the teachers knowledge about } \\
\text { the stages of the educational project }\end{array}$ & 0.855 \\
\hline $\mathbf{V}_{\mathbf{1 8}}$ & $\begin{array}{c}\text { The importance of the teachers knowledge of the } \\
\text { methods of reporting on completed projects }\end{array}$ & 0.834 \\
\hline $\mathbf{V}_{\mathbf{1 6}}$ & $\begin{array}{c}\text { The importance of the teachers knowledge of the } \\
\text { interdisciplinary connections of mathematics } \\
\text { topics }\end{array}$ & 0.827 \\
\hline $\mathbf{V}_{\mathbf{2 1}}$ & $\begin{array}{c}\text { The importance of teachers knowledge about ICT } \\
\text { in education }\end{array}$ & 0.817 \\
\hline $\mathbf{V}_{\mathbf{1 4}}$ & $\begin{array}{c}\text { The importance of the teachers knowledge about } \\
\text { the essence of students' project activities }\end{array}$ & 0.753 \\
\hline $\mathbf{V}_{\mathbf{1 7}}$ & $\begin{array}{c}\text { The importance of the teachers knowledge of } \\
\text { modern Internet resources }\end{array}$ & 0.675 \\
\hline
\end{tabular}

Factor 1 indicates Mathematics teachers' beliefs about the importance of teachers knowledge regarding the nature and procedure of PBL and PBT Mathematics. Therefore, it is called the Content-Technological Factor. According to the interviewed teachers, the most significant aspects are the teachers knowledge of ways to motivate and the features of evaluating the results of students' project activities. In general, according to the respondents, a teacher needs thorough knowledge of the project implementation stages and the technological capabilities of ICT and the Internet in providing and supporting PBL and PBT Mathematics. We should note also the high level of the variable $V_{16}$ significance (the importance of the teachers knowledge of the interdisciplinary links of topics in Mathematics). At the same time, the survey has found that teachers are more interested in the practical aspects of applying these educational techniques than in the theoretical explorations that interpret their essence.

Factor 2 (Result \& Age Factor) combined Mathematics teachers' beliefs about the importance of using PBL and PBT Mathematics for the effectiveness of mastering certain units of mathematical content and the feasibility of its application in K5-11. This factor is called Result \& Age Factor. In general, teachers are convinced that the study of Mathematics in modern conditions is impossible without the use of the project method. It can be applied in K5-11. According to the respondents, this method is the most effective for students to learn new mathematical facts and new mathematical concepts. It is not so effective for the formation of new mathematical methods of activity in students. These aspects are of a paramount importance to teachers who believe that PBL and PBT Mathematics should be implemented in grades 7-9.

Table 7. Factor 2 (Result \& Age Factor)

\begin{tabular}{|c|c|c|}
\hline $\mathbf{N o}$ & Variables & \\
\hline $\mathbf{V}_{\mathbf{6}}$ & $\begin{array}{c}\text { The influence of PBL and PBT on the } \\
\text { effectiveness of learning new mathematical facts }\end{array}$ & 0.813 \\
\hline $\mathbf{V}_{\mathbf{5}}$ & $\begin{array}{c}\text { The influence of PBL and PBT on the } \\
\text { effectiveness of students' learning of new } \\
\text { mathematical concepts }\end{array}$ & 0.763 \\
\hline $\mathbf{V}_{\mathbf{1 0}}$ & $\begin{array}{c}\text { The expediency of using PBL and PBT in } \\
\text { teaching Mathematics in grades 7-9 }\end{array}$ & 0.753 \\
\hline $\mathbf{V}_{\mathbf{7}}$ & $\begin{array}{c}\text { The influence of PBL and PBT on the } \\
\text { effectiveness of learning new ways of } \\
\text { mathematical activity }\end{array}$ & 0.704 \\
\hline $\mathbf{V}_{\mathbf{8}}$ & $\begin{array}{c}\text { Significance of students' project activities for } \\
\text { studying Mathematics in modern conditions }\end{array}$ & 0.682 \\
\hline $\mathbf{V}_{\mathbf{9}}$ & $\begin{array}{c}\text { The expediency of using PBL and PBT in } \\
\text { teaching Mathematics in grades 5-6 }\end{array}$ & 0.572 \\
\hline $\mathbf{V}_{\mathbf{1 1}}$ & $\begin{array}{c}\text { The expediency of using PBL and PBT in } \\
\text { teaching Mathematics in grades 10-11 }\end{array}$ & 0.458 \\
\hline
\end{tabular}

Table 8. Factor 3 (Factor of the Target Audience)

\begin{tabular}{|c|c|c|}
\hline № & Variables & \\
\hline $\mathbf{V}_{\mathbf{1 1}}$ & $\begin{array}{c}\text { The expediency of using PBL and PBT in } \\
\text { teaching Mathematics in grades 10-11 }\end{array}$ & 0.701 \\
\hline $\mathbf{V}_{\mathbf{9}}$ & $\begin{array}{c}\text { The expediency of using PBL and PBT in } \\
\text { teaching Mathematics in grades 5-6 }\end{array}$ & -0.614 \\
\hline
\end{tabular}

Factor 3 (Factor of the Target Audience on the expediency of using PBL and PBT Mathematics) shows a tendency that if a teacher uses PBL and PBT Mathematics in grades 10-11, he/she is convinced that such educational practice should not be used in teaching mathematics to students in grades 5-6. Teachers who teach Mathematics in grades 7-9 do not demonstrate such beliefs.

Table 9. Factor 4 (Teacher's Overload Factor)

\begin{tabular}{|c|c|c|}
\hline № & Variables & \\
\hline $\mathbf{V}_{\mathbf{3}}$ & $\begin{array}{c}\text { Grade levels where the teacher works } \\
\text { simultaneously }\end{array}$ & 0.696 \\
\hline $\mathbf{V}_{\mathbf{1 3}}$ & $\begin{array}{c}\text { Knowledge of the PBL and PBT essence is not } \\
\text { important for a teacher }\end{array}$ & 0.775 \\
\hline
\end{tabular}

Factor 4 (Teacher's Overload Factor) finds "hidden" inhibitory factors in the use of PBL and PBT Mathematics. It points out that if a teacher is "overloaded" by teaching in different grades from 5 to 11 at the same time, he/she believes that knowledge of the essence of PBL and PBT Mathematics is not important to him. This, in its turn, inhibits the effectiveness of the application of these educational practices, since the deep differences between PBL and PBT Mathematics and just "doing projects", which are described in detail in [26], are leveled.

Table 10. Factor 5 (Praxeological Factor)

\begin{tabular}{|c|c|c|}
\hline № & Variables & \\
\hline $\mathbf{V}_{\mathbf{1 2}}$ & $\begin{array}{c}\text { The respondent has sufficient, in his/her opinion, } \\
\text { knowledge about the essence of PBL and PBT }\end{array}$ & 0.789 \\
\hline $\mathbf{V}_{\mathbf{4}}$ & Experience in application of PBT Mathematics & 0.683 \\
\hline $\mathbf{V}_{\mathbf{2}}$ & Experience as a Mathematics teacher & -0.547 \\
\hline
\end{tabular}


Factor 5 (Praxeological Factor) indicates that teachers who have experience in the use of PBL and PBT Mathematics generally believe that they are sufficiently familiar with the essence of this method of teaching. An important statistically verified result of our study is that teacher's experience is not an influential factor for the use of PBL and PBT Mathematics.

Table 11. Factor 6 (Locality Factor)

\begin{tabular}{|c|c|c|}
\hline № & Variables & \\
\hline $\mathbf{V}_{\mathbf{1}}$ & City/village & 0.912 \\
\hline
\end{tabular}

Factor 6 (Locality Factor) finds the importance of the influence of where the teacher works (in the city or in the village) on the process of using PBL and PBT Mathematics. The presence of this factor turned out to be quite unexpected for us. Its profound effects require more detailed study.

Table 12. Factor 7 (Teacher's Awareness Spectrum Factor)

\begin{tabular}{|c|c|c|}
\hline № & Variables & \\
\hline $\mathbf{V}_{\mathbf{2 2}}$ & $\begin{array}{c}\text { The importance of other teachers knowledge for } \\
\text { PBT Mathematics }\end{array}$ & 0.902 \\
\hline
\end{tabular}

Factor 7 (Teacher's Awareness Spectrum Factor) indicates respondents' belief that a teacher who is not only "doing projects" but implements PBL and PBT Mathematics should have quite a wide range of additional knowledge. To the question: "What other types of knowledge does a teacher need in order to organize students' project activities?" free answers of the respondents are grouped as follows: 1) thorough knowledge of mathematics; 2) knowledge of the latest and traditional practical applications and applied aspects of mathematics; 3) knowledge of psychological, pedagogical and age features of a child's development; 4) knowledge about the interests and features of interpersonal communication of modern students; 5) negative answers, such as: "Project activities are worse than any other, to study Mathematics", "This method takes a lot of time, but there is a catastrophic lack of time".

Table 13. The results of teachers' ranking certain types of knowledge necessary for the successful application of PBL and PBT Mathematics

\begin{tabular}{|c|c|}
\hline Type of knowledge & Points \\
\hline $\begin{array}{c}\text { Knowledge about interdisciplinary links of educational } \\
\text { themes in Mathematics }\end{array}$ & 4.53 \\
\hline $\begin{array}{c}\text { Knowledge about the ways of motivating students for } \\
\text { project activity }\end{array}$ & 4.51 \\
\hline Awareness of current educational Internet resources & 4.49 \\
\hline $\begin{array}{c}\text { Knowledge about steps of learning project performance } \\
\text { by students }\end{array}$ & 4.45 \\
\hline $\begin{array}{c}\text { Knowledge about pedagogical software that facilitates } \\
\text { project implementation }\end{array}$ & 4.42 \\
\hline Knowledge about the essence of students' project activity & 4.38 \\
\hline $\begin{array}{c}\text { Knowledge about ways of reporting on completed } \\
\text { projects }\end{array}$ & 4.34 \\
\hline $\begin{array}{c}\text { Knowledge about features of outcome evaluation of } \\
\text { students' project activity }\end{array}$ & 4.31 \\
\hline
\end{tabular}

One of the focuses of the study was to elaborate and present some prospective directions for improving the preparation of the pre-service Mathematics teachers for providing the PBL and PBT Mathematics. We were especially interested in what knowledge, in the opinion of teachers-practitioners, a future Mathematics teacher should acquire in the process of his/her professional training. The respondents were asked to rank (in points from 0 to 5) the importance of some kind of knowledge for prospective teachers to apply PBL and PBT Mathematics efficiently. The results are shown in Table 13. A more detailed analysis can be found in [31].

\section{Conclusions}

It is argued in our study that modern Mathematics teachers believe that it is impossible to teach Mathematics for modern students without using PBL and PBT. On the one hand, teachers demonstrate their belief in these educational techniques. On the other hand, the survey reveals hidden factors that are inhibitory factors in the practice of PBL and PBT Mathematics.

Preliminary consideration of the study results has led to the assumption that the experience of the teacher is an influential factor in the practice of teaching Mathematics using PBL and PBT. According to the respondents' answers, the teachers having 16-25 years of work experience (100\%) use PBL and PBT often or sometimes; at the same time, the teachers having 1-5 years of work experience do not use it at all (13\%). This fact has led to the assumption that the newly qualified teachers do not feel sufficiently prepared for the organization the schoolchildren's PBL and PBT Mathematics. In support of this assumption, the study has found that the largest number of those who often use project-based teaching in their work (35\%) is presented among the teachers having 11-15 years of work experience. The teachers with work experience of more than 25 years always (19\%) or sometimes $(70 \%)$ use this method in Mathematics educational process. However, the assumption that the experience of a Mathematics teacher is an influential factor in the use of PBL and PBT has not been statistically confirmed. Experience as a Mathematics teacher appeared to be not a statistically significant factor.

The study reveals such statistically confirmed factors in teachers' beliefs concerning the use of PBL and PBT Mathematics: 1) Content-Technological Factor; 2) Result $\&$ Age Factor; 3) Factor of the Target Audience on the expediency of using PBL and PBT Mathematics; 4) Teacher's Overload Factor; 5) Praxeological Factor; 6) Locality Factor; 7) Teacher's Awareness Spectrum Factor.

The most influential factor (Content-Technological Factor) aggregates Mathematics teachers' beliefs about the significance of the teacher's knowledge concerning the nature and procedure of PBL and PBT Mathematics. 
Teachers express their beliefs about the importance of teachers' knowledge of ways to motivate students to implement projects, the interdisciplinary links of topics in mathematics and their applied and practical aspects, didactic and technological support of the stages of projects, the specifics of evaluating project activities, ICT and Internet capabilities in providing and supporting PBL and PBT Mathematics. Teachers give priority to practical awareness and experience in the application of these educational technologies.

The study has found that the range of additional knowledge of teachers (Teacher's Awareness Spectrum Factor), according to respondents, should be sufficiently wide. The teacher has to have a thorough knowledge of mathematics, be familiar with the latest and traditional practical applications of mathematics; be aware of the psychological, pedagogical and age characteristics of the development of modern children who are growing and developing in the era of digital technologies; understand the interests and features of interpersonal communication of modern students. An influential factor (Teacher's Overload Factor) was the teacher overload factor in teaching Mathematics simultaneously in different (by age) classes during one school year.

A rather unexpected influential factor was the Locality Factor, that is, whether the teacher of Mathematics works in a city or a village. Its origins (genesis and causes) and the consequences of the influence of this factor on educational processes in Ukraine need more detailed study.

\section{REFERENCES}

[1] Ed. Winter. "21st Century Competencies: Foundation Document for Discussion. Phase 1: Towards Defining 21st Century Competencies for Ontario". 2016. 70 p. http://www.edugains.ca/resources21CL//About21stCentury/ 21CL_21stCenturyCompetencies.pdf. (accessed. May,1, 2020).

[2] Project Based Learning. Edutopia.http://www.edutopia.org/ project-based-learning (accessed. July, 7, 2020).

[3] Project Based Learning for the 21st Century. Buck Institute for Education. http://www.bie.org (accessed. July, 7, 2020).

[4] Maida Carl A. "Project-Based Learning: a Critical Pedagogy for the Twenty-First Century Policy Futures in Education". Policy Futures in Education, 2011, 9(6). https://www.researchgate.net/publication/275685844_Proje ct-Based_Learning_A_Critical_Pedagogy_for_the_TwentyFirst_Century. doi: 10.2304/pfie.2011.9.6.759.

[5] Markham T., Larmer J., \& Ravirz J. "Project-based Learning Handbook: a Guide to Standards-Focused Project-Based Learning for Middle and High School Teachers", 2nd edn. Novato, CA: Buck Institute for Education. 2003.

[6] Meltzoff A.N., Kuhl P.K., Movellan J. \& Sejnowsky T.J.
"Foundations for a New Science of Learning", Science, July, 2009, pp. 284-288.

[7] Dewey J. "The School and Society". 1900. https://archive.org/details/schoolsociety00dewerich/page/16 4 (accessed. June, 7, 2020).

[8] Dewey J. "Democracy and Education". 1916. https://en.wikisource.org/wiki/Democracy_and_Education (accessed. June, 7, 2020).

[9] Kilpatrick W.H. "Foundations of Method: informal talks on teaching". 1925.https://babel.hathitrust.org//cgi/pt?id=mdp. 39015057278676; view=1up;seq=7 (accessed. June, 7, 2020).

[10] Makarenko A.S. "Oput metodiku rabotu detskoy trudovoy colonii" [Experience of working methods of a children's labor colony]. Moskow, Russia: Pedogogika. 1983. [In Rus.].

[11] Thomas J. W. "A review of research on project-based learning”. San Rafael, CA: The Autodesk Foundation. 2000.

[12] Condliffe B., Quint J., Visher G. M., Bangse, M. R. Drohojowska S., Saco L., \& Nelson E. "Project-Based Learning. A Literature Review". New York, NY: MDRC. 2017.

[13] Balkevicius M., Mazeikiene A., Svediene S. "The first steps of project-based education in Lithuanian high schools". In Procedia - Social and Behavioral Sciences, 2013, no. 83, pp. 483-492. http://www.sciencedirect.com (accessed June, 17, 2020).

[14] Ertmer P. A. "Teacher pedagogical beliefs: The final frontier in our quest for technology integration?" In Educational Technology Research and Development, 2005, no. 53(4), pp. 25-39.

https://link.springer.com/article//10.1007/BF02504683. (accessed June, 23, 2020).

[15] Mohedo M. T., Bújez A. V. "Project Based Teaching as a Didactic Strategy for the Learning And Development of Basic Competences in Future Teachers". In Procedia - Social and Behavioral Sciences, 2014, no. 141, pp. 232 - 236.

[16] Douladeli E. "Experiential Education Through Project Based Learning". In Procedia - Social and Behavioral Sciences, 2014, no. 152, pp. 1256 - 1260.

[17] Ergül N. R., Kargın E. K. "The Effect Of Project Based Learning On Students' Science Success". In Procedia Social and Behavioral Sciences, 2014, no. 136, pp. 537 541.

[18] Fernandes S., Mesquita D., Flores M. A., \& Lima R. M. "Engaging students in learning: findings from a study of project-led education". In European Journal of Engineering Education, 2014, no. 39(1), pp. 55-67.

[19] Tarasenkova N. A., Akulenko I. A. "Determination of Students' Beliefs is one of the Aspects of Competence Oriented System of Mathematics Teachers' Methodical Preparation". In American Journal of Educational Research, 2013, vol. 1, no. 11, pp. 477-483.

[20] Larmer J., Mergendoller J. R. "Seven Essentials for Project-Based Learning”. In Educational Leadership, 2010, vol. 68 , no. 1 , pp. $34-37$.

[21] Frey K. "Die Projectmethode". Berlin, Germany: 
BeltzWeinheim. 1991.

[22] Ertmer P. A. "Teacher pedagogical beliefs: The final frontier in our quest for technology integration?". In ETR\&D, 2005, no. 53, pp. 25-39. https://doi.org/10.1007/BF02504683

[23] Albion P., Ertmer P. A. "Beyond the foundations: The role of vision and belief in teachers' preparation for integration of technology”. In TechTrends, 2002, no. 46(5), pp. 34-38.

[24] Block J. H., \& Hazelip K. "Teachers' beliefs and belief systems". In L. W. Anderson (Ed.), International encyclopedia of teaching and teacher education (2nd ed). New York: Pergammon, 1995, pp. 25-28.

[25] Calderhead J. "Teachers: Beliefs and knowledge". In D. Berliner, \& R. Calfee (Eds.). Handbook of Educational Psychology. New York: Macmillan Library Reference, 1996, pp. 709-725.

[26] Lee J. "An Inquiry-Based Approach: Project-Based Learning". In Rigor, Relevance, and Relationship; Making Mathematics Come Alive with Project-Based Learning by National Council of Teachers of Mathematics, Inc., (NCTM Stock no.14798), 2018.

[27] Krajcik J. S., \& Blumenfeld Ph. "Project-Based Learning". In (ed. by R. K. Sawyer). The Cambridge handbook of the learning sciences. New York, Cambridge, 2006, pp. 317-334.
[28] Grant M. M., \& Hill J. R. "Weighing the risks with the rewards: Implementing student-centered pedagogy within high-stakes testing”. In R. G. Lambert and C. J. McCarthy (Eds.), Understanding teacher stress in an age of accountability. Greenwich, CT: Information Age Press, 2006, pp. 19-42.

[29] Tarasenkova N. (Eds). "Conceptual framework for improving the mathematical training of young people: Monograph". In L. Kyba (A. Ed.). Budapest, Hungary: SCASPEE, 2016.

[30] Tarasenkova, N. (Eds). "Current Status and Prospects of Mathematical Education: Monograph". In L. Kyba (A. Eds.). Budapest, Hungary: SCASPEE, 2018.

[31] Akulenko I., Zhydkov O., \& Yakovenko A. "Project-Based Learning and Teaching Mathematics: Theoretical Framework and Teachers' Beliefs". In (Eds. prof. N. Tarasenkova). Current issues in ensuring the quality of mathematical education: monograph. Budapest, Hungary: SCASPEE, 2019, pp. 167-186.

[32] Ramadhani R., Fitri Yu., "A Project-Based Learning into Flipped Classroom for ePUB3 Electronic Mathematics Learning Module (eMLM)-based on Course Design and Implementation". In Universal Journal of Educational Research, Vol. 8, No. 7, 2020, pp. 3119-3135. DOI: 10.13189/ujer.2020.080740. 